\title{
Increased sow nutrition during midgestation affects muscle fiber development and meat quality, with no consequences on growth performance ${ }^{1}$
}

\author{
A. Cerisuelo, ${ }^{*}$ M. D. Baucells, ${ }^{*}$ J. Gasa, ${ }^{*}$ J. Coma,$\dagger$ D. Carrión, $\ddagger$ \\ N. Chapinal,* and R. Sala*2 \\ *Animal Nutrition, Management and Welfare Research Group, Universitat Autònoma de Barcelona, \\ 08193 Bellaterra, Spain; †Vall Companys Group, 25191 Lleida, Spain; \\ and $\ddagger$ Pig Improvement Company, S.A., 08190 Sant Cugat del Vallès, Spain
}

\begin{abstract}
Pregnant sow nutrition has potential effects on the muscle fiber development of progeny in utero. A total of 199 Landrace $\times$ Large White sows from parities 0 to 6 and their offspring were used to evaluate the effects of increasing the feeding amount during midpregnancy on the muscle tissue, growth performance, and meat quality of the progeny. The experiment was divided into 2 study replicates, and in each replicate, sows were assigned to 1 of the 2 treatments: 1) sows in the control group (C sows) were fed 2.5 to $3.0 \mathrm{~kg} / \mathrm{d}$ (feed: $12.1 \mathrm{MJ}$ of $\mathrm{ME} / \mathrm{kg}$ and $0.62 \%$ lysine) throughout gestation; and 2) sows in the high group ( $\mathrm{H}$ sows) received an extra feed allowance of $1.5 \mathrm{~kg} / \mathrm{d}$ for gilts and $2.0 \mathrm{~kg} / \mathrm{d}$ for multiparous sows above the $\mathrm{C}$ amount from d 45 to 85 of gestation (period of secondary muscle fiber formation). Sow backfat was recorded on $\mathrm{d} 40$ and 85 of gestation. Sow performance (litter size and piglet $\mathrm{BW}$ ) at farrowing and on d 18 of lactation was measured. At weaning, pigs were divided into $5 \mathrm{BW}$ groups/treatment, and progeny growth performance was measured during the nursery $(n=958)$ and the growing-finishing $(n=636)$ periods. At slaughter, carcass and meat quality traits (lean content, main cut
\end{abstract}

weight, $\mathrm{pH}$, Minolta color, and drip loss) were recorded from the second lightest group at weaning (BW group $4 ; \mathrm{n}=90$ ), and samples from the longissimus thoracis muscle were taken to study muscle fiber characteristics $(n=70$ ). The extra nutrition from d 45 to 85 of gestation did not lead to differences in litter size or piglet $\mathrm{BW}$ at farrowing and on d 18 of lactation. Pigs born to $\mathrm{H}$ mothers had fewer muscle fibers and fewer estimated primary and secondary fibers than did pigs born to $\mathrm{C}$ mothers $(P<0.05)$. However, postnatal growth performance was not consistently affected by the maternal treatment. The smaller number of muscle fibers found in the $\mathrm{H}$ group of pigs was associated with fewer type IIB fibers $(P<0.05)$ with greater cross-sectional areas $(P<0.10)$, which might be related to the significantly greater meat $\mathrm{pH}$ at $24 \mathrm{~h}$ postmortem and the smaller $L^{*}$ (lightness) values recorded in the $H$ group of pigs. Results from the present study confirm the existence of effects of maternal nutrition on fetal development, at least in terms of muscle tissue development and meat quality, although with no beneficial effects were found for the postnatal growth performance of the progeny.

Key words: growth performance, meat quality, muscle fiber, pregnancy feeding, sow

\section{INTRODUCTION}

The knowledge of how maternal nutrition during pregnancy affects fetal growth and muscle fiber development is of great interest in the pig industry. Positive effects on the number of muscle fibers and on postnatal growth were reported when extra feed was provided to sows during primary (Pr) fiber formation (d 25 to 50 of gestation; Dwyer et al., 1994; Gatford et al., 2003). However, in recent studies, feed supplementation during this part of gestation has shown no clear effects, or has even had disadvantageous effects, on the progeny (Nissen et al., 2003; Bee, 2004; Heyer et al., 2004). Nis-

\footnotetext{
'The authors gratefully acknowledge the help and very useful comments as well as the technical assistance of Marta Gil (Institut de Recerca i Tecnologia Agroalimentàries, Monells, Spain) and Charlotte Rehfeldt (Forschungsinstitut für die Biologie landwirtschaftlicher Nutzticre, Dummerstorf. Germany). Appreciation is also expressed to the Generalitat de Catalunya for financial support.

${ }^{2}$ Corresponding author: roser.sala (cinab.cat

Received October 23, 2007.

Accepted October 19, 2008.
} 
sen et al. (2003) speculated that extra feeding from d 50 to 70 of gestation, covering the period of secondary (Sc) muscle fiber formation, might overrule this disadvantage. In fact, Sc muscle fibers are reported to be more susceptible to environmental factors, such as maternal nutrition, than are Pr fibers (Wigmore and Stickland, 1983; Gatford et al., 2003). The effects of maternal nutrition on fetal muscle fiber development during this gestational window of time have been poorly documented. In addition, information is lacking on the effects of this feeding strategy on carcass and meat quality traits.

Evidence exists suggesting that muscle growth processes might affect meat quality. The total number of muscle fibers has been positively correlated with lean meat percentage (Larzul et al., 1997). In addition, based on the metabolic and contractile properties of muscle, both muscle fiber morphology and muscle fiber type may influence postmortem metabolic changes in converting muscle to meat, and thereby influence meat quality (Karlsson et al., 1999; Franck et al., 2007). The relationship of fiber composition to meat quality has not been fully established or validated in pigs (Lefaucheur, 2006)

The present study assessed the implications of an increased feed allowance to sows from d 45 to 85 of gestation on the muscle fiber development and postnatal performance of the progeny. Additionally, the effects on pig carcass and meat quality traits were studied.

\section{MATERIALS AND METHODS}

The experimental protocols used in this study received previous approval from the Animal Protocol Review Committee of the Universitat Autònoma de Barcelona (Spain). Management, housing, and husbandry conditions conformed to European Union guidelines.

\section{Animals and Treatments}

The study was performed in 2 study replicates $(\mathbf{R})$ conducted under identical conditions. A total of 199 Camborough PIC sows (Landrace $\times$ Large White; L02 $\times$ L03 PIC line, R1: 103; R2: 96 ) from parities 0 to 6 were allotted to 2 experimental groups at $\mathrm{d} 40$ of pregnancy. Sows were blocked by parity, day of mating, and body reserves [backfat thickness (BF) and BCS], and randomly assigned to 1 of 2 treatment groups (control group, $\mathbf{C}$ sows; high group, $\mathbf{H}$ sows). Body condition score was measured on a scale of 1 to 5 [BCS 1 (poor score condition) to BCS 5 (grossly fat)] according to Close and Cole (2003). Table 1 shows the sow parity distribution across treatments. The boar line used for mating was the White Duroc (Large White $\times$ Duroc; L-8 PIC line). The 2 groups of sows differed in the feeding amount of a standard commercial sow feed that was allowed during midgestation (12.1 MJ of $\mathrm{ME} / \mathrm{kg}$ of feed, $14.6 \%$ protein, and $0.62 \%$ lysine; Table 2 ). Throughout gestation, the $\mathrm{C}$ sows ( $\mathrm{R} 1: \mathrm{n}=49$; $\mathrm{R} 2: \mathrm{n}=46$ ) were
Table 1 . Sow parity distribution across treatments ${ }^{1}$

\begin{tabular}{lcc}
\hline \hline \multirow{2}{*}{ Sow parity } & \multicolumn{2}{c}{ Maternal treatment $^{2}$} \\
\cline { 2 - 3 } 0 & Control, n & High, n \\
\hline 1 & 28 & 32 \\
2 & 18 & 21 \\
3 & 19 & 20 \\
4 & 15 & 13 \\
$>4$ & 8 & 11 \\
\hline
\end{tabular}

${ }^{1} \mathrm{n}=$ number of animals.

"Maternal treatments: sows in the control gronp were fed 2.5 to 3.0 $\mathrm{kg} / \mathrm{d}$ (feed: $12.1 \mathrm{MJ}$ of $\mathrm{ME} / \mathrm{kg}$ and $0.62 \%$ lysine) throughout gestation, and sows in the high group received an extra feed allowance (1.5 $\mathrm{kg} / \mathrm{d}$ for gilts and $2.0 \mathrm{~kg} / \mathrm{d}$ for multiparous sows) from d 45 to 85 of gestation.

fed 2.5 to $3.0 \mathrm{~kg} / \mathrm{d}$ according to their BCS at mating. Sows in the $\mathrm{H}$ group ( $\mathrm{R} 1: \mathrm{n}=54 ; \mathrm{R} 2: \mathrm{n}=50$ ) received an extra allowance of the same feed $[1.5 \mathrm{~kg} / \mathrm{d}$ for gilts (parity 0 ) and $2.0 \mathrm{~kg} / \mathrm{d}$ for multiparous sows] above the $\mathrm{C}$ amount from d 45 to 85 of gestation. During gestation, sows were housed in individual stalls, fed dry feed twice daily ( 0800 and $1430 \mathrm{~h}$ ), and had free access to water. All sows were maintained under identical feeding conditions from mating to $\mathrm{d} 45$ of gestation and from $\mathrm{d}$ 85 of gestation to parturition.

Routine farm management procedures were followed in caring for the sows and litters during parturition and lactation. Table 2 shows the composition of the lactation diet. Pigs were counted and individually weighed at parturition and on d $18 \pm 1$ of lactation. Litter size was adjusted to 10 to 11 pigs per litter at $24 \mathrm{~h}$ postfarrowing. Because only the male pig progeny were followed during the nursery and growing-finishing periods, cross-fostering was allowed only for female piglets and between sows from the same treatment. No creep feeding was provided to the piglets. Male piglets were castrated on $\mathrm{d} 7$ after birth.

After weaning at $3 \mathrm{wk}$ of age, all pigs were phasefed identically to exceed NRC (1998) nutrient requirements for their specific BW until they reached market BW (Table 2). The male progeny [(Landrace $\times$ Large White) $\times$ Durocj of $\mathrm{C}$ and $\mathrm{H}$ sows were followed during the nursery ( $\mathrm{n}=958$; $\mathrm{C}: 476, \mathrm{H}: 482$ ) and growing-finishing periods ( $\mathrm{n}=636$ barrows; C: $318, \mathrm{H}: 318)$. The nursery period lasted $6 \mathrm{wk}$, and the growing-finishing phase lasted $13(\mathrm{R} 1)$ and 16 (R2) wk. At the beginning of the nursery period, pigs were classified according to BW into 5 groups per treatment (group 1, $8.8 \pm 0.56$ $\mathrm{kg}$; group 2, 7.8 $\pm 0.39 \mathrm{~kg}$; group $3,7.0 \pm 0.39 \mathrm{~kg}$; group 4, $6.3 \pm 0.55 \mathrm{~kg}$; and group 5, 5.0 $\pm 0.41 \mathrm{~kg}$ ) and organized according to group and maternal treatment in $20 \mathrm{pens} / \mathrm{R}$ of 20 to $26 \mathrm{pigs} / \mathrm{pen}$. Body weight group included representatives from several litters. Pigs were maintained within the same group through the growing-finishing period until slaughter. In the growing-finishing period, pigs were allocated in 20 to 30 pens/ $R$ of 12 to 13 animals each. 
Table 2. Composition and nutrient content of the experimental diets (as-fed basis)

\begin{tabular}{|c|c|c|c|c|c|}
\hline \multirow[b]{2}{*}{ Item } & \multicolumn{2}{|c|}{ Sow diet } & \multicolumn{3}{|c|}{ Pig diet } \\
\hline & Gestation & Lactation & $\begin{array}{l}\text { From weaning } \\
\text { to } 35 \mathrm{~kg} \text { of } \mathrm{BW}\end{array}$ & $\begin{array}{l}\text { From } 35 \mathrm{to} \\
65 \mathrm{~kg} \text { of } \mathrm{BW}\end{array}$ & $\begin{array}{c}\text { From } 65 \mathrm{~kg} \\
\text { of BW to slanghter }\end{array}$ \\
\hline \multicolumn{6}{|l|}{ Ingredient, \% } \\
\hline Barley & 22.5 & 27.4 & & 8.6 & \\
\hline Wheat bran & 42.0 & 22.4 & & 2.1 & \\
\hline Wheat & 8.9 & 12.1 & 9.4 & & \\
\hline Corn & & & 42.0 & 20.0 & \\
\hline Rye & & & 4.1 & & \\
\hline Sorghum & & & & & 13.0 \\
\hline Rapeseed meal & & & & & 9.7 \\
\hline Sugar beet molasses & 6.1 & 5.0 & 2.0 & 2.0 & 4.9 \\
\hline Cassava meal & & & 6.0 & 20.4 & 35.7 \\
\hline Bakery by-products & & & 6.0 & 10.1 & \\
\hline Soybean meal, $44 \%$ & 6.1 & 17.6 & 20.1 & 31.7 & 21.8 \\
\hline Sunflower meal & 7.5 & 6.0 & & & 3.8 \\
\hline Animal fat & 4.8 & & 4.4 & 2.9 & 6.1 \\
\hline Soybean oil & & 2.4 & & & \\
\hline Olive pulp & & 3.8 & & & \\
\hline Lysine $50 \%$ & 0.15 & 0.15 & 0.96 & 0.16 & 0.01 \\
\hline DL-Methionine $88 \%$ & & & 0.22 & 0.12 & 0.07 \\
\hline Choline $75 \%$ & & & 0.03 & 0.02 & 0.02 \\
\hline Threonine $50 \%$ & & & 0.37 & & \\
\hline Limestone & 1.43 & 1.60 & 0.91 & 0.79 & 0.59 \\
\hline Dicalcium phosphate & & 0.60 & 0.60 & 0.35 & 0.49 \\
\hline Acid liquid ${ }^{1}$ & & & 0.81 & & \\
\hline Salt & 0.25 & 0.47 & 0.38 & 0.36 & 0.32 \\
\hline Vitamin and mineral premix ${ }^{2}$ & 0.50 & 0.50 & 0.52 & 0.51 & 0.51 \\
\hline \multicolumn{6}{|l|}{ Calculated composition } \\
\hline $\mathrm{ME}, \mathrm{MJ} / \mathrm{kg}$ & 12.1 & 12.8 & 13.9 & 13.5 & 13.5 \\
\hline Crude fat, $\%$ & 7.26 & 8.1 & 7.2 & 5.6 & 7.2 \\
\hline Crude fiber, $\%$ & 7.52 & 6.4 & 3.4 & 4.9 & 6.3 \\
\hline $\mathrm{CP}, \%$ & 14.57 & 17.7 & 15.1 & 18.5 & 17.7 \\
\hline Lysine, \% & 0.62 & 0.90 & 1.18 & 1.06 & 0.95 \\
\hline Methionine, \% & 0.25 & 0.27 & 0.40 & 0.37 & 0.34 \\
\hline Methionine + cysteine, $\%$ & 0.53 & 0.58 & 0.67 & 0.68 & 0.65 \\
\hline Threonine, $\%$ & 0.52 & 0.62 & 0.73 & 0.60 & 0.69 \\
\hline Tryptophan, \% & 0.19 & 0.22 & 0.17 & 0.23 & 0.22 \\
\hline Valine, \% & 0.71 & 0.81 & 0.70 & 0.88 & 0.83 \\
\hline Calcium, $\%$ & 0.70 & 0.91 & 0.59 & 0.59 & 0.62 \\
\hline Available phosphorus, $\%$ & 0.26 & 0.35 & 0.29 & 0.26 & 0.20 \\
\hline
\end{tabular}

'Acid liquid is a blend of formic acid $(75 \%)$ and propionic acid $(25 \%)$ as an acidifier.

${ }^{2}$ Provided, per kilogram of feed: $10,000 \mathrm{IU}$ of vitamin $\mathrm{A} ; 2,000$ IU of vitamin $\mathrm{D}_{3} ; 40 \mathrm{mg}$ of vitamin $\mathrm{E} ; 6 \mathrm{mg}$ of vitamin $\mathrm{K}: 1 \mathrm{mg}$ of vitanin $\mathrm{B}_{1} ; 6$ $\mathrm{mg}$ of vitamin $\mathrm{B}_{2} ; 0.02 \mathrm{mg}$ of vitamin $\mathrm{B}_{12} ; 29 \mathrm{mg}$ of nicotinic acid; $11.71 \mathrm{mg}$ of pantothenic acid: $0.5 \mathrm{mg}$ of folic acid, $0.06 \mathrm{mg}$ of biotin; $80 \mathrm{mg}$ of iron: $25 \mathrm{mg}$ of copper; $0.40 \mathrm{mg}$ of cobalt; $100 \mathrm{mg}$ of zinc; $43.20 \mathrm{mg}$ of manganese: $2.25 \mathrm{mg}$ of iodine and $0.09 \mathrm{mg}$ of selenimu.

\section{Sows and Pig Performance}

At the beginning and end of the experimental period (on d 45 and d 85 of gestation), BF was measured ultrasonically in sows at the $\mathrm{P} 2$ position (above the last rib at approximately 6.0 to $6.5 \mathrm{~cm}$ from the midline) using an A-mode ultrasound device (Renco sonograder 4.2, Renco Corporation, Minneapolis, MN).

For the postweaning growth performance study, pigs were weighed every week in the nursery phase and every $3 \mathrm{wk}$ in the growing-finishing phase to calculate ADG by pen. Average daily feed intake and G:F were obtained from all pens in the nursery period and in groups 3 and 4 in the growing-finishing period.

\section{Carcass and Meat Quality Measurements and Muscle Sample Collection}

Carcass, meat quality, and muscle fiber characteristies were studied at market BW in pigs from group 4 (carcass and meat quality: $\mathrm{n}=90$; muscle fiber study: $n=70$ ). The reason for selecting this BW group (group 4) was that, although not significant, the smallest BW groups (groups 4 and 5) showed the greatest growth performance between treatments during the nursery period. Pigs from group 5 were avoided because this group might include runts or less healthy pigs.

Pigs from group 4 were slanghtered at an average BW of $104.1 \pm 1.16 \mathrm{~kg}$ in $\mathrm{R} 1$ and $120.9 \pm 2.65 \mathrm{~kg}$ in 
R2. Carcass weight, percentage of lean meat content (Fat-O-Meat'er, SFK, Herlev, Denmark), and midline fat thickness at the gluteus medius were measured immediately after slaughter, before the chilling process. At 45 min postmortem, $\mathrm{pH}$ was measured at the last rib in the left longissimus thoracis (LT) and semimembranosus (SM) muscles by using a handheld Crison micropH $2001 \mathrm{~m} \mathrm{pH}$ meter with a xerolite electrode (Crison, Barcelona, Spain). The left ham and loin were then removed from the carcass and weighed; the weight of the SM muscle also was recorded. Three consecutive cranial slices of the LT muscle were taken from the last rib. The first slice (from the last rib to the interface between the 12th and 13th ribs) was used to perform the meat quality measurements $(\mathrm{pH}$ and meat color) and to obtain samples for histochemistry (addressed below); the second slice was photographed to measure the muscle cross-sectional area by using an image analysis system (Digital Image System SL, Barcelona, Spain), and the third slice was taken to determine the water-holding capacity, measured as the drip loss percentage.

At $24 \mathrm{~h}$ postmortem, $\mathrm{pH}\left(\mathbf{p H}_{24}\right)$ and meat reflectance (Minolta Chroma Meter CR300, Minolta, Osaka, Japan) measurements were obtained. Meat color determinations were made in the transverse cut of the LT muscle by using the Comission Internationale de l'Eclairage (1976) values ( $L^{*}$, lightness; $a^{*}$, redness; and $\mathrm{b}^{*}$, yellowness). The instrument was calibrated according to the instructions of the manufacturer. The $\mathrm{pH}_{24}$ was measured in the SM muscle and at the last rib in the LT muscle. Drip loss was measured over $24 \mathrm{~h}$ on a cylindrical sample of approximately $2.5 \mathrm{~cm}$ in diameter maintained at $4^{\circ} \mathrm{C}$, using the plastic tub method described by Rasmussen and Andersson (1996).

In addition, in R2, one more 4-cm-wide slice caudal to the last rib was obtained from the LT muscle of each animal, frozen immediately at $-20^{\circ} \mathrm{C}$, and kept at this temperature until a texture profile analysis test (TPA) was performed (Bourne, 1978). The TPA was performed using a TA-TX2 Texture Analyzer (State Micro System, Survey, UK). Each slice of LT was thawed for $24 \mathrm{~h}$ at $4^{\circ} \mathrm{C}$ and cooked in a gas oven. A total of 6 to 8 sample cubes $\left(1 \times 1.5 \times 1.5 \mathrm{~cm}^{3}\right)$ per slice were used for the analysis. The study of the resulting curve force time led to the extraction of 6 textural variables: cohesiveness, adhesiveness $(\mathrm{g} / \mathrm{s})$, springiness, hardness $(\mathrm{g})$, gumminess $(\mathrm{g})$, and chewiness $(\mathrm{g})$. Mean values for each animal were obtained by averaging all the samples per animal $(n=6$ to 8$)$.

\section{Histochemistry}

Five cube-shaped muscle samples (approximately 1 $\mathrm{cm}^{3}$ ), evenly distributed over the cross-sectional area of the portion of LT, were taken according to Cerisuelo et al. (2007). The cubes were cut parallel to the longitudinal myofiber axis, placed on a cork surface, embedded in optimum control temperature embedding medium (TissueTeck, Sakura, Zoeterwoude, the Netherlands) and talcum powder, snap-frozen in liquid nitrogen, and stored in a $-80^{\circ} \mathrm{C}$ ultracold freezer until histochemical analyses.

Transverse serial sections $(10 \mu \mathrm{m})$ were cut in a cryostat (Leica CM 1900, Leica, Nussloch, Germany) at $-15^{\circ} \mathrm{C}$, placed on silane-treated microscope slides, and allowed to thaw and dry at room temperature for 1 to $2 \mathrm{~h}$. The sections were then stained for myosin adenosine triphosphatase activity after alkaline ( $\mathrm{pH} 10.3)$ and acid ( $\mathrm{pH} 4.40$ and 4.45 ) incubation, according to the method described by Latorre et al. (1993). This allowed muscle fibers to be classified as type I, IIA, or IIB, depending on their $\mathrm{pH}$ lability. Alkaline-incubated sections were used to calculate the number and mean area of fiber types I, IIA, and IIB through a computerassisted image analysis system (Digital Image System SL). All measurements were made by the same person to reduce any potential subjective variability to a minimum. For each sample (5 samples/animal), measurements were made on at least 300 fibers (at least 1,500 fibers/animal). These data were then used to calculate the percentages of type I, IIA, and IIB fibers and the mean area of each fiber type. In addition, the total number of fibers was estimated as the number of fibers counted per animal (sum of the 5 samples) multiplied by the muscle cross-sectional area $\left(\mathrm{cm}^{2}\right)$, all divided by the sum of the areas of the fibers counted per animal $\left(\mathrm{cm}^{2}\right)$.

The numbers of developmental $\mathrm{Pr}$ and Sc fibers were estimated on the basis of the type I clusters. A previous study by Wigmore and Stickland (1983) suggested that in the pig, one of the central slow fibers in each cluster was a Pr myofiber, whereas all others developed as $\mathrm{Sc}$ fibers. Therefore, it is possible to estimate the number of $\mathrm{Pr}$ and Sc fibers formed prenatally through the number of type I clusters in the adult animal (Pr) and their subtraction from the estimated total number of fibers (Sc).

\section{Statistical Analyses}

Data were analyzed using SAS (SAS Inst. Inc., Cary, $\mathrm{NC})$. In all cases, the gestation feeding amount served as the treatment factor. Study $\mathrm{R}$ and the interaction between maternal treatment and study $R$ were tested for significance. Because the interaction between maternal treatment and study $\mathrm{R}$ was not significant ( $P$ $>0.10$ ), $\mathrm{R}$ was included as a block factor in all analyses performed. In the postweaning growth performance analysis, group was considered a class factor, and the interaction between maternal treatment and group was included in the statistical model.

In maternal data analyses, sow was considered the experimental unit. Backfat amounts and changes were analyzed using ANOVA (GLM procedure), in which BF on $\mathrm{d} 45$ were used as a covariate. The total number of pigs born, the number born alive, the number stillborn, and the number of pigs on $\mathrm{d} 18$ of lactation were analyzed through a statistical model for count data (GEN- 
Table 3. Sow body reserves during gestation and lactation, and litter performance at birth and on d 18 of lactation

\begin{tabular}{|c|c|c|c|c|}
\hline \multirow[b]{2}{*}{ Item } & \multicolumn{2}{|c|}{ Maternal treatmont $^{1}$} & \multirow[b]{2}{*}{$\mathrm{SEM}^{2}$} & \multirow[b]{2}{*}{$P$-value" } \\
\hline & Control & High & & \\
\hline Sow, n & 95 & 104 & & \\
\hline $\mathrm{BF}^{+}$on d 45 of gestation, $\mathrm{mm}$ & 16.8 & 16.6 & 0.34 & 0.692 \\
\hline $\mathrm{BF}^{+}$on $\mathrm{d} 85$ of gestation, $\mathrm{mm}$ & 18.0 & 20.0 & 0.26 & $<0.001$ \\
\hline $\mathrm{BF}^{4}$ change from $\mathrm{d} 45$ to $\mathrm{d} 85, \mathrm{~mm}$ & 1.29 & 3.36 & 0.293 & $<0.001$ \\
\hline Total pigs born, $\mathrm{n}^{5}$ & 13.0 & 12.7 & 0.33 & 0.628 \\
\hline$A P W,{ }^{6} \mathrm{~kg}$ & 1.45 & 1.51 & 0.021 & 0.057 \\
\hline Pigs born alive, $\mathrm{n}^{5}$ & 12.0 & 11.7 & 0.305 & 0.988 \\
\hline $\mathrm{APW},{ }^{1} \mathrm{~kg}$ & 1.47 & 1.51 & 0.022 & 0.156 \\
\hline $\mathrm{CV}, \%$ & 19.4 & 19.4 & 0.75 & 0.995 \\
\hline Pigs stillborn, $n^{5}$ & 1.02 & 0.95 & 0.117 & 0.660 \\
\hline Pigs on d 18 of lactation, ${ }^{5} \mathrm{n}$ & 9.85 & 9.49 & 0.150 & 0.150 \\
\hline $\mathrm{APW}^{6} \mathrm{~kg}$ & 5.44 & 5.49 & 0.077 & 0.654 \\
\hline ADG. ${ }^{\top} \mathrm{kg} / \mathrm{d}$ & 2.29 & 2.20 & 0.060 & 0.302 \\
\hline
\end{tabular}

${ }^{1}$ Materual treatment: control sows were fed 2.5 to $3.0 \mathrm{~kg} / \mathrm{d}$ (feed: $12.1 \mathrm{MJ}$ of $\mathrm{ME} / \mathrm{kg}$ and $0.62 \%$ lysine) throughout gestation and sows in the high group received an extra feed allowance of $1.5 \mathrm{~kg} / \mathrm{d}$ for gilts ancl 2.0 $\mathrm{kg} / \mathrm{d}$ for multiparous sows from d 45 to 85 of gestation.

${ }^{2}$ SEM was extracted from the ANOVA analysis in count data (number of total born, born alive, stillborn and number of pigs on $d 18$ of lactation).

${ }^{3} P$-value refers to effects of maternal treatment.

${ }^{4} \mathrm{BF}=$ backfat thickness at the last rib at approximately 6.0 to $6.5 \mathrm{~cm}$ from the midline.

${ }^{5} \mathrm{n}=$ number of pigs per litter.

"APW $=$ average piglet BW.

'Average daily gain per litter during lactation (after cross-fostering to d 18 of lactation).

MOD procedure). Average piglet BW at birth and at d 18 of lactation were evaluated through a one-way ANOVA (GLM procedure); litter size was used as a covariate term for average piglet $\mathrm{BW}$. For piglet $\mathrm{BW}$ on d 18 of lactation, piglet BW after cross-fostering was used as a covariate. Intralitter variation was tested through the CV (\%).

Pen was considered the experimental unit for postweaning growth performance (ADG, ADFI, and G:F), whereas for carcass, meat quality, and muscle fiber trait analyses the experimental unit was the pig. Growth performance was analyzed through a 2-way ANOVA (GLM procedure). Differences in carcass, meat quality, and muscle fiber measurements were tested through a one-way ANOVA (GLM procedure). For the muscle fiber type analysis, when data were expressed as percentages, they were subjected to a square-root arcsine transformation to achieve a normalized distribution before ANOVA. Pearson correlation coefficients (CORR procedure) were calculated to examine the relationships between diverse meat quality traits and muscle fiber characteristics. Statistical significance was $\alpha \leq$ 0.05 , and $0.05<\alpha<0.10$ was considered a trend.

\section{RESULTS}

\section{Sows Performance}

Sow productivity and body-reserve balances during gestation are recorded in Table 3 . In general, $\mathrm{H}$ sows gained more $(P<0.001) \mathrm{BF}$ during the experimental period (from d 45 to 85 of gestation), leading to greater
BF on d 85 of gestation compared with $\mathrm{C}$ sows $(P<$ $0.001)$.

No consistent differences were found in the number of pigs at birth (total number, number born alive, and number stillborn) and on $\mathrm{d} 18$ of lactation. The $\mathrm{H}$ group of sows showed a tendency for a greater piglet BW at birth for the total born $(P=0.057)$, which was not observed for pigs born alive and pigs on d 18 of lactation. Neither the intralitter piglet BW variation (CV) at birth nor the ADG of litters during lactation was different between treatments.

\section{Postweaning Growth Performance}

Growth performance throughout the nursery and growing-finishing periods is recorded in Table 4. During the nursery period, pigs born to $\mathrm{H}$ sows showed greater ADG and G:F than did pigs born to $\mathrm{C}$ sows ( $P$ $<0.05$ ). However, these differences between treatments disappeared in the growing-finishing phase.

During the nursery period, the group factor exorted a strong effect, regardless of the treatment, on ADG rates and feed consumption $(P<0.001$; Table 4$)$. Initially, the heavier the pigs were (group 1), the greater their growth and feed intake. In this regard, pigs from group 1 showed ADG of $380 \mathrm{~g} / \mathrm{d}$ and ADFI of $520 \mathrm{~g} / \mathrm{d}$, whereas pigs from group 5 showed ADG of $276 \mathrm{~g} / \mathrm{d}$ and ADFI of $375 \mathrm{~g} / \mathrm{d}$. However, no consistent differences were found between groups in G:F efficiency. In the growing-finishing phase, differences in ADG between groups were still evident but were smaller than in the nursery period $(P=0.07)$. 
Table 4. Nursery and growing-finishing growth performance of piglets from sows in the control $(\mathrm{C})$ or high $(\mathrm{H})$ group during gestation

\begin{tabular}{|c|c|c|c|c|c|c|}
\hline \multirow[b]{2}{*}{ Period } & \multicolumn{2}{|c|}{ Maternal treatment $^{t}$} & \multirow[b]{2}{*}{ SEM } & \multicolumn{3}{|c|}{$P$-value ${ }^{2}$} \\
\hline & $\mathrm{C}$ & $\mathrm{H}$ & & $\mathrm{MT}$ & $\mathrm{G}$ & $\mathrm{MT} \times \mathrm{G}$ \\
\hline \multicolumn{7}{|l|}{ Nursery } \\
\hline Pigs, 11 & 476 & 482 & & & & \\
\hline $\mathrm{ADG}, \mathrm{g} / \mathrm{d}$ & 321.4 & 333.2 & 3.67 & 0.031 & $<0.001$ & 0.540 \\
\hline ADFI. $\mathrm{g} / \mathrm{d}$ & 442.3 & 451.3 & 5.26 & 0.233 & $<0.001$ & 0.764 \\
\hline $\mathrm{G}: \mathrm{F}$ & 0.72 & 0.74 & 0.004 & 0.044 & 0.490 & 0.170 \\
\hline \multicolumn{7}{|c|}{ Growing-finishing } \\
\hline Pigs, n & 317 & 319 & & & & \\
\hline $\mathrm{ADG}, \mathrm{g} / \mathrm{d}$ & 798.3 & 785.4 & 8.89 & 0.938 & 0.073 & 0.547 \\
\hline ADFI ${ }^{3} \mathrm{~g} / \mathrm{d}$ & 1.819 .2 & $1,816.0$ & 29.2 & 0.310 & 0.165 & 0.379 \\
\hline $\mathrm{G}: \mathrm{F}^{3}$ & 0.44 & 0.43 & 4.6 & 0.275 & 0.293 & 0.421 \\
\hline
\end{tabular}

${ }^{1}$ Matemal treatment: sows in the C group were fed 2.5 to $3.0 \mathrm{~kg} / \mathrm{d}$ (feed: $12.1 \mathrm{MJ}$ of $\mathrm{ME} / \mathrm{kg}$ and $0.62 \%$ lysine) throughout gestation, and sows in the $\mathrm{H}$ group received an extra feed allowance $(1.5 \mathrm{~kg} / \mathrm{d}$ for gilts and $2.0 \mathrm{~kg} / \mathrm{d}$ for multiparous sows) from $\mathrm{d} 45$ to 85 of gestation.

${ }^{2}$ Effects of maternal treatmont (MT), piglet BW group $(\mathrm{G})$ and the interaction term.

${ }^{3}$ Feed cousumption controlled in groups 3 and 4.

The interaction term between maternal treatment and BW group was not significant in any of the growth performance traits measured $(P>0.10)$. However, during the nursery phase, a trend toward a greater benefit from maternal feed supplementation was observed in pigs from the lightest group (groups 4 and 5) for G:F $(P=0.095$, data not shown $)$.

\section{Carcass and Meat Quality}

The most important carcass (weight, lean meat percentage, and midline fat thickness at the gluteus medius) and meat quality traits $(\mathrm{pH}$, color, and waterholding capacity) measured from the selected pigs are summarized in Table 5. Increased maternal feed intake during midpregnancy did not lead to differences in carcass weight, lean meat content, midline fat thickness at the gluteus medius, or main cut weight of the progeny. Regarding meat quality traits, $\mathrm{pH}_{24}$ values and meat color traits were influenced by the maternal treatment. Pigs from the $\mathrm{H}$ group showed significantly greater $\mathrm{pH}_{24}$ $(P<0.01)$ in the SM muscle. In addition, H-group pigs showed smaller $\mathrm{L}^{*}$ values in the LT muscle $(P<0.01)$. No differences were found for water-holding capacity (drip loss values) between treatments. A correlation analysis of these data showed that $\mathrm{pH}_{24}$ was negatively related to both $\mathrm{L}^{*}(\mathrm{r}=-0.41, P<0.001)$ and drip loss ( $\mathrm{r}=-0.33, P=0.003)$, and $\mathrm{L}^{*}$ was positively associated with drip loss measurements $(\mathrm{r}=0.24, P=0.030)$. Results from the TPA performed in a cooked portion of the LT muscle showed no differences between treatment groups for any of the instrumental texture variables measured (Table 6).

\section{Muscle Fiber Characteristics}

Estimated total number of muscle fibers and number of $\operatorname{Pr}$ and Sc fibers formed in the prenatal period (estimated through the number of type I clusters) are recorded in Figure 1. Increasing the maternal feeding amount during midpregnancy led to a smaller total number of muscle fibers in the LT muscle of progeny compared with the progeny of $\mathrm{C}$ sows $\left[\mathrm{C}\left(\times 10^{3}\right)=\right.$ 1837.8 , and $\left.\mathrm{H}\left(\times 10^{3}\right)=1,627.9 ; P=0.01\right]$. Maternally supplemented pigs showed fewer Pr and Sc fibers than did pigs born to $\mathrm{C}$ sows $(P<0.01)$. This led to similar Sc-to-Pr fiber ratios (approximately 24 to $25 \mathrm{Sc}$ fibers per Pr fiber) between treatments.

The maternal treatment applied during midgestation (from d 45 to 85 of gestation; Table 7 ) led to fewer estimated type IIB fibers $(P<0.01)$, but did not affect the numbers of type I and type IIA fibers. From the calculated proportions of each fiber type, pigs born to $\mathrm{H}$ sows had a smaller percentage of type IIB fibers $(P$ $<0.01)$ and greater percentages of type I and IIA fibers $(P<0.05)$ compared with pigs born to $\mathrm{C}$ sows.

The smaller number of muscle fibers in pigs born to the $\mathrm{H}$ sows (Figure 1) was linked to a greater mean cross-sectional area of those fibers (Table 7). Overall, the mean cross-sectional area of muscle fibers was greater $(P<0.05)$ in pigs born to $\mathrm{H}$ sows than in those born to $\mathrm{C}$ sows. This difference between treatments derived from the larger IIB fibers observed in the LT muscle of pigs born to $\mathrm{H}$ sows (Table $7 ; P<0.01$ ).

\section{DISCUSSION}

\section{Maternal Feeding Amount and Sow Performance}

All sows gained BF during the experimental period, but extra feed offered during midgestation led to greater $\mathrm{BF}$ gains in the $\mathrm{H}$ sows than in the $\mathrm{C}$ sows $(+2.1 \mathrm{~mm})$. However, this feeding strategy did not significantly affect farrowing output or performance during the suckling period. Consequently, no impact of maternal feed supplementation on milk production was detected. Several studies have reported that in well-managed sows, BW at birth is not generally affected by increasing the sow feeding amounts (complete diet, energy and pro- 
Table 5. Carcass and meat quality traits at slaughter from pigs at market BW from group $4^{1}$

\begin{tabular}{|c|c|c|c|c|}
\hline \multirow[b]{2}{*}{ Item } & \multicolumn{2}{|c|}{ Maternal treatment ${ }^{2}$} & \multirow[b]{2}{*}{ SEM } & \multirow[b]{2}{*}{ P-value } \\
\hline & Control & High & & \\
\hline Pigs, n & 45 & 45 & & \\
\hline \multicolumn{5}{|l|}{ Carcass quality } \\
\hline Carcass wt, kg & 79.9 & 82.3 & 1.54 & 0.268 \\
\hline Lean meat, $\%$ & 54.17 & 53.01 & 0.583 & 0.166 \\
\hline $\mathrm{GM}^{4}{ }^{4} \mathrm{~mm}$ & 20.06 & 20.45 & 0.733 & 0.711 \\
\hline \multicolumn{5}{|c|}{ Muscle and main cut wt, $\mathrm{kg}$} \\
\hline$S M^{i}$ & 1.08 & 1.11 & 0.021 & 0.219 \\
\hline $\mathrm{LT}^{\mathrm{i}}$ & 2.83 & 2.90 & 0.122 & 0.621 \\
\hline Ham & 11.87 & 12.32 & 0.210 & 0.126 \\
\hline \multirow{2}{*}{\multicolumn{5}{|c|}{$\begin{array}{l}\text { Ment quality } \\
\mathrm{pH}_{4,}{ }^{i}\end{array}$}} \\
\hline & & & & \\
\hline $\mathrm{SM}^{5}$ & 6.21 & 6.18 & 0.034 & 0.520 \\
\hline $\mathrm{LT}^{6}$ & 6.18 & 6.21 & 0.033 & 0.577 \\
\hline \multicolumn{5}{|l|}{$\mathrm{pH}_{2.4}{ }^{\mathrm{N}}$} \\
\hline $\mathrm{SM}^{5}$ & 5.57 & 5.66 & 0.021 & 0.002 \\
\hline $\mathrm{LT}^{(i}$ & 5.50 & 5.57 & 0.013 & 0.331 \\
\hline \multicolumn{5}{|l|}{ Mrat color" } \\
\hline $\mathrm{L}^{*}$ & 52.89 & 50.89 & 0.463 & 0.003 \\
\hline$a^{*}$ & 5.49 & 5.78 & 0.165 & 0.213 \\
\hline 1$)^{*}$ & 4.16 & 4.15 & 0.183 & 0.952 \\
\hline Drip loss, ${ }^{111} \%$ & 1.12 & 1.30 & 0.100 & 0.203 \\
\hline
\end{tabular}

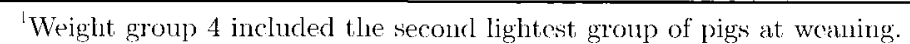

"Maternal treatment: sows in the control group were fed 2.5 to $3.0 \mathrm{~kg} / \mathrm{d}$ (feed: $12.1 \mathrm{MJ}$ of $\mathrm{ME} / \mathrm{kg}$ and $0.62 \%$ lysine) thromghout gestation, and sows in the high group received an extra foed allowance $(1.5 \mathrm{~kg} / \mathrm{d}$ for gilts and $2.0 \mathrm{~kg} / \mathrm{d}$ for multiparous sows) above the control amount from d 45 to 85 of gestation.

"P-value refers to the effects of niaternal treatment.

${ }^{\mathrm{I}} \mathrm{GM}=$ midline fat thickness at glutens nedins.

"SM = seminembranosus muscle.

${ }^{4} \mathrm{LT}=$ longissinus thoracis muscle.

${ }^{\mathrm{T}} \mathrm{pH}_{4,5}=\mathrm{pH}$ at $45 \mathrm{~min}$ postmortem.

${ }^{*} \mathrm{pH}_{24}=\mathrm{pH}$ a.t $24 \mathrm{~h}$ postmortem.

"Meat color ( $\mathrm{L}^{*}$, lightness; $\mathrm{a}^{*}$, redness; $b^{*}$, yollowness) measured at 24 h postmortem in the LT muscle.

${ }^{10}$ Measured at $24 \mathrm{~h}$ postmorten in the LT muscle.

tein) in different stages of pregnancy, and even during the last month of gestation, when fetal requirements are the greatest (Dwyer et al., 1994; Miller et al., 2000; Heyer et al., 2004). Supplementary feeding in these cases increased maternal tissue accretion but did not affect the composition of the products of conception (Speer, 1990; Miller et al., 2000).

Dwyer et al. (1994) reported that a consequence of increasing sow feed intake in gestation would be a decrease in the distribution of piglet BW at birth within

Table 6. Instrumental texture analyzed according to a texture profile analysis test in the longissimus thoracis muscle in pigs from the group $4^{l}$ of the second study replicate

\begin{tabular}{|c|c|c|c|c|}
\hline \multirow[b]{2}{*}{ Variable } & \multicolumn{2}{|c|}{ Maternal treatment } & \multirow[b]{2}{*}{$\mathrm{SEM}$} & \multirow[b]{2}{*}{$P$-value } \\
\hline & Control & High & & \\
\hline $\mathrm{n}$ & 20 & 20 & & \\
\hline Cohesiveness & 0.573 & 0.567 & 0.0040 & 0.317 \\
\hline Adhesiveness, g/s & 6.22 & 5.72 & 0.578 & 0.542 \\
\hline Springiness & 1.01 & 1.01 & 0.001 & $0.606 \bar{j}$ \\
\hline Harduess, $g$ & $7,976.0$ & $8,315.7$ & 284.0 & 0.4033 \\
\hline Gumminess, g & $4,576.7$ & 4.723 .0 & 167.2 & 0.540 \\
\hline Chewiness, g & $4,635.3$ & $4,785.3$ & 169.8 & 0.536 \\
\hline
\end{tabular}

\footnotetext{
'Body weight group 4 included the scond lightest group of pigs at weaning.

${ }^{2}$ Maternal treatment: sows in the control group were fed 2.5 to $3.0 \mathrm{~kg} / \mathrm{d}$ (feed: $12.1 \mathrm{MJ}$ of $\mathrm{ME} / \mathrm{kg}$ ancl $0.62 \%$ lysine) throughout gestation, and sows in the high group received an extra foed allowanco (1.5 kg $\mathrm{k} / \mathrm{d}$ for gilts and $2.0 \mathrm{~kg} / \mathrm{d}$ for multiparous sows) from d 45 to 85 of gestation.

${ }^{3} \mathrm{P}$-value refers to the effects of matiernal treatment.
} 
Table 7. Muscle fiber characteristics in the longissimus thoracis muscle from pigs at market BW from group $4^{1}$

\begin{tabular}{|c|c|c|c|c|}
\hline \multirow[b]{2}{*}{ Item } & \multicolumn{2}{|c|}{ Maternal treatment $^{2}$} & \multirow[b]{2}{*}{ SEM } & \multirow[b]{2}{*}{$P$-value ${ }^{3}$} \\
\hline & Control & High & & \\
\hline Pigs, 11 & 35 & 35 & & \\
\hline Longissinus thoracis area, $\mathrm{cm}^{2}$ & 71.0 & 69.0 & 1.59 & 0.360 \\
\hline \multicolumn{5}{|c|}{ Total number of nuscle fibers, ${ }^{4} \times 10^{3}$} \\
\hline Type I & 156.1 & 157.8 & 7.47 & 0.874 \\
\hline Type IIA & 114.8 & 124.9 & 8.81 & 0.412 \\
\hline Type IIB & $1,566.8$ & $1,345.0$ & 43.41 & $<0.001$ \\
\hline \multicolumn{5}{|l|}{ Fiber type composition, $/ /$} \\
\hline Type I & 8.6 & 9.7 & 0.37 & 0.038 \\
\hline Type IIA & 6.2 & 7.6 & 0.40 & 0.020 \\
\hline Type IIB & 85.2 & 83.1 & 0.52 & 0.006 \\
\hline \multicolumn{5}{|l|}{ Mean fiber area, $\mu n^{2}$} \\
\hline Total & $3,989.1$ & $4,338.2$ & 102.44 & 0.016 \\
\hline Type I & $3,796.6$ & $3,818.4$ & 116.87 & 0.893 \\
\hline Type IIA & $2,051.9$ & $2,109.4$ & 69.13 & 0.549 \\
\hline Type IIB & $4,158.3$ & $4,629.0$ & 110.76 & 0.003 \\
\hline
\end{tabular}

${ }^{1}$ Body weight group 4 included the second lightest group of pigs at weaning.

"Maternal treatment: sows in the control group were fed 2.5 to $3.0 \mathrm{~kg} / \mathrm{d}$ (feed: $12.1 \mathrm{MJ}$ of $\mathrm{ME} / \mathrm{kg}$ and $0.62 \%$ lysine) throughout gestation, and sows in the high group received an extra feed allowance $(1.5 \mathrm{~kg} / \mathrm{d}$ for gilts and $2.0 \mathrm{~kg} / \mathrm{dl}$ for multiparous sows) from d 45 to 85 of gestation.

${ }^{3} P$-value refers to the effects of maternal treatment.

${ }^{t}$ Estimated total number of muscle fibers calculated as [(total number of fibers counted $\times$ muscle cross-sectional area)/area occupied by the fibers counted].

a litter. The reason is that increasing the feed allowance to the mother would increase the fetal growth and fiber numbers of the nutritionally disadvantaged pigs at birth, but would not affect the largest pigs in the litter. This hypothesis could not be confirmed by the results of the intralitter $\mathrm{CV}$ obtained in the present study because no differences between treatments were obtained.

\section{Maternal Feeding Amount, Muscle Fiber Development, and Postweaning Performance}

In mammals, muscle fiber hyperplasia is completed around birth and postnatal muscle growth is hypertrophic (Swatland and Cassens, 1973; Wigmore and Stickland, 1983). Myogenesis in the pig is a biphasic phenomenon that consists of a sequential formation of 2 fiber populations. Primary fibers develop from d 35 to 60 of gestation. Secondary muscle fibers are formed thereafter (d 54 to 90-95 of gestation), using Pr fibers as templates (Swatland and Cassens, 1973; Wigmore and Stickland, 1983). Despite the hypothesis that increasing the maternal feeding amount during gestation has positive effects on postnatal growth, its real effects remain controversial. Dwyer et al. (1994) and Gatford et al. (2003) reported improvements in the number of $\mathrm{Sc}$ muscle fibers when increasing the maternal feed allowance from d 25 to 50 of gestation. Additionally, in these studies positive effects were described on progeny growth rates after $70 \mathrm{~d}$ of age (Dwyer et al., 1994) and until $27 \mathrm{~d}$ of age (Gatford et al., 2003). However, other more recent studies have described no consistent effects, and even negative effects in some cases, on the development of muscle fiber numbers (Nissen et al., 2003; Bee, 2004) and on growth performance (Nissen et al., 2003;

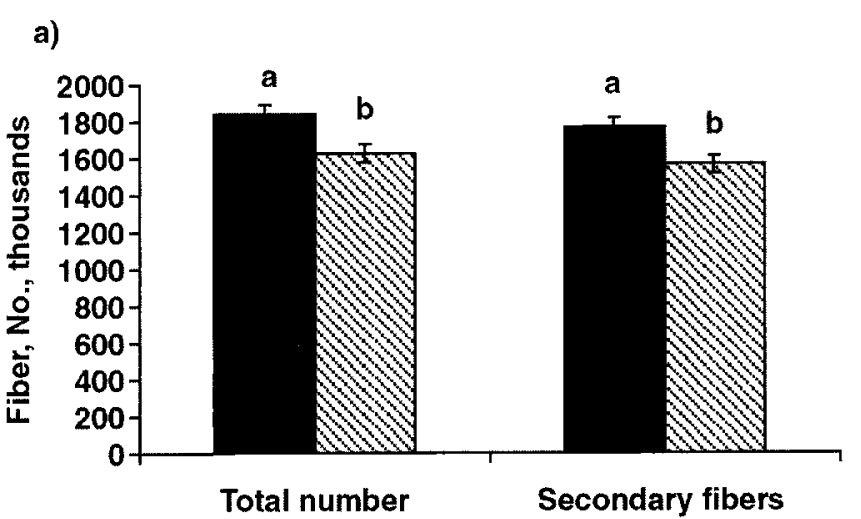

b)

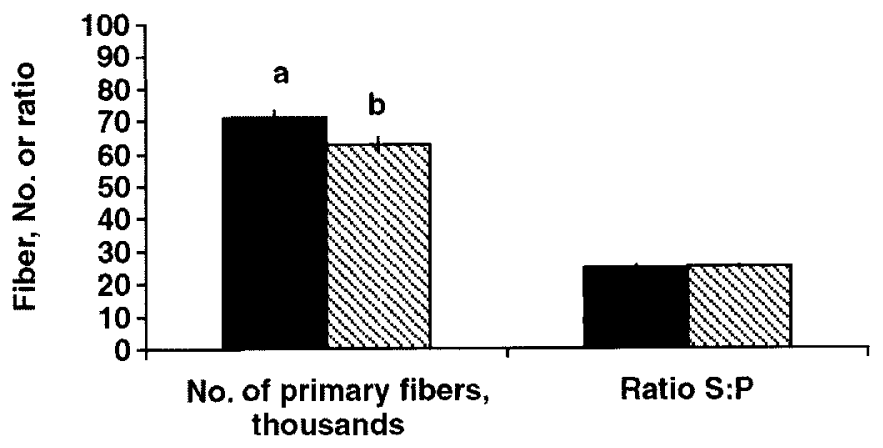

Figure 1. Muscle fiber characteristics in the longissinus thoracis muscle from pigs born to sows in the control group (fed conventionally throughout gestation; solid bars) and to sows in the high group (provicled 1.5 and $2.0 \mathrm{~kg} / \mathrm{d}$ extra for gilts and multiparous, respectively, from d 45 to 85 of gestation; hatched bars). a) Estimated total number of muscle fibers $(P=0.005)$ and total number of embryonic socondary fibers $(P=0.005)$. b) Total number of embryonic primary fibers $(P=0.007$ ) and ratio of secondary to primary fibers (ratio $\mathrm{S}: \mathrm{P}, P=$ 0.725 ). ${ }^{a .1}$ Witlin a graph, bars that no have common letters differ ( $P$ $<0.01$ ). 
Heyer et al., 2004; Musser et al., 2006; Lawlor et al., 2007 ) when the feed allowance is increased during the same period of gestation. Factors such as the time period and duration of treatment during gestation, the type and magnitude of nutrient changes involved, the litter size, and sow parity have been suggested as important factors causing variation between studies (Bee, 2004).

Most of the studies mentioned above involved the period before Sc muscle fiber formation (d 25 to 50 of gestation) or the entire myogenesis period (d 25 to 90 of gestation) in their investigations. In the present research, the increased feeding allowance covered the period of Sc muscle fiber formation and, contrary to what was expected, led to a smaller number of muscle fibers in the LT muscle of the progeny compared with pigs born to $\mathrm{C}$ sows. This reduction in the number of fibers affected both the Sc and Pr fiber populations.

In spite of the greater susceptibility of Sc fibers to variation in the uterine environment (Wigmore and Stickland, 1983; Gatford et al., 2003), little evidenco has been provided in the literature regarding the impact on fetal muscle tissue of maternal nutrition during the window of time studied in the present experiment. Dwyer et al. (1994) included this time frame in their investigation and found no significant differences in the number of fibers in the semitendinosus muscle when feed supplementation was provided from d 50 to 80 of gestation compared with controls $\left[\mathrm{C}\left(\times 10^{3}\right)=371.0\right.$ and $\left.\mathrm{H}\left(\times 10^{3}\right)=360.4\right]$. In a more recent study (Hoshi et al., 2005), the effects of supplementing pregnant sows with ractopamine from d 50 to 80 of gestation resulted in a smaller calculated total number of muscle fibers in the semitendinosus muscle compared with controls [C $\left(\times 10^{3}\right)=396.6$ and $\left.\mathrm{H}\left(\times 10^{3}\right)=388.8\right]$. Thus, extra feed supplementation to sows during the period of Sc muscle fiber generation might be detrimental for muscle fiber hyperplasia of the fetus.

The diminution in muscle fiber numbers in the present study involved both $\mathrm{Pr}$ and Sc developmental fiber populations. Because Pr fibers constitute the framework for Sc fibers to be formed, we speculated that maternal nutrition could have been directed to Pr muscle fiber formation. Wigmore and Stickland (1983) studied the evolution of fetal muscle fiber development throughout pregnancy and established that the number of Pr fibers was fixed on d 60 of gestation. Increasing nutrient availability during this time could have both prevented final $\operatorname{Pr}$ fiber formation and induced degeneration of the existing Pr fibers. With fewer Pr fibers, a smaller number of Sc fibers would subsequently be developed. The real cause of this consistent effect requires further investigation. Studies on maternal transference of metabolites to the fetus, or an understanding of the epigenetic alterations caused by the maternal nutritional status on the fetal genome (Wu et al., 2004) may help to elucidate the underlying mechanisms involved. In addition, it would be necessary to address whether sow parity or other related factors that could contribute to differences in maternal metabolism might play a role in this effect.

Despite the differences observed in the number of muscle fibers between treatments, no consistent effects on postnatal piglet growth performance were detected in the current study. Although differences in growth performance between treatment groups appeared in the nursery period, they disappeared thereafter and did not seem linked to muscle fiber numbers. However, muscle mass and muscle growth do not depend only on the number of muscle fibers, but also on the rate of hypertrophy of the individual fibers (Henckel et al., 1997; Larzul et al., 1997; Rehfeldt et al., 2000). In the present study, the total number of fibers and their mean cross-sectional areas were negatively associated, similar to other reports (Rehfeldt et al., 2000). Therefore, the smaller number of muscle fibers found in the maternally supplemented pigs could have been compensated for by a greater hypertrophy of these fibers during the growing period. This would then give a suitable explanation for the lack of differences in growth performance during the growing-finishing phase, despite the differences found in the number of muscle fibers between treatments. As a result, final carcass lean content at market BW was not affected by the maternal treatment. Similarly, Nissen et al. (2003) and Heyer et al. (2004) found no effects of increasing maternal feed intake during gestation on carcass composition of the progeny at slaughter.

Although effects on growth performance were not found, the pigs that were smaller in utero seemed to benefit the most from the maternal treatment, with better feed conversion rates. In the present study, this led us to select pigs from group 4 to carry out the planned carcass, meat quality, and muscle fiber measurements. Dwyer et al. (1994) and Rehfeldt et al. (2001) also stated that the lightest pigs in the litter (which, in the present study, were mainly the pigs allocated to groups 4 and 5) showed the greatest response to maternal feeding or maternal treatment, respectively, during pregnancy.

\section{Maternal Feeding Amount, Muscle Fiber Development, and Meat Quality}

The different feed allowances provided to the sows in the present study resulted in meat quality differences that were consistent in both study R. To our knowledge, other studies in which a supplemental feeding strategy has been applied during early gestation (d 25 to 50, approximately) or covering both $\mathrm{Pr}$ and $\mathrm{Sc}$ muscle fiber formation (approximately $25 \mathrm{~d}$ to 70 to 80 d) have not reported differences in meat quality traits at slaughter (Nissen et al., 2003; Heyer et al., 2004). In the present study, pigs born to $\mathrm{H}$ sows showed greater ultimate $\mathrm{pH}$ values in the $\mathrm{SM}$ muscle $\left(\mathrm{pH}_{2.1}\right)$ and darker LT meats (reduced $\mathrm{L}^{*}$ values) than pigs born to $\mathrm{C}$ sows. These differences between treatments were not followed 
by differences in drip loss percentages. The histochemical and biochemical properties of a given muscle, such as the number of muscle fibers, the mean area, or the fiber type composition (oxidative and glycolytic capacities and glycogen and lipid contents) are factors that influence meat quality (Larzul et al., 1997; Karlsson et al., 1999; Oksbjerg et al., 2000; Rehfeldt et al., 2004). However, the relationship between fiber type composition and meat quality has not been fully established or validated for pigs (Lefaucheur, 2006). In the present study, apart from the above-mentioned differences in the number and size of the muscle fibers, different maternal feed allowances during midgestation affected muscle composition. Pigs born to $\mathrm{H}$ sows showed fewer type IIB fibers and a decreased percentage of type IIB fibers together with greater percentages of type I and IIA fibers compared with $\mathrm{C}$ pigs. In agreement with the glycolytic potential and the white color of the type IIB fibers, the dark color and greater ultimate $\mathrm{pH}$ of meat from the $\mathrm{H}$ animals might have originated from the smaller total number and proportion of this type of muscle fiber (Larzul et al., 1997; Depreux et al., 2002). In fact, in the present experiment, the estimated total number of type IIB fibers was positively related to lightness $(\mathrm{r}=0.32)$ and negatively associated with the ultimate $\mathrm{pH}(\mathrm{r}=-0.30)$.

Experiments focusing on the effects of genetic selection for lean content based on muscle fiber characteristics have reported that an increase in the proportion. of type IIB fibers may be one of the causes of reduced meat quality characteristics reported for the new leaner genotypes (Larzul et al., 1997; Oksbjerg et al., 2000). Because of their glycolytic metabolism and smaller number of capillary networks, type IIB fibers seem to be detrimental to pork quality and particularly susceptible to PSE development (Lefaucheur et al., 2002, 2003; Franck et al., 2007). As a whole, through changes caused in proportions of fiber types, the feeding strategy carried out in the current study might have helped to improve meat quality and prevent the PSE condition in the pigs born to $\mathrm{H}$ sows. However, it is important to highlight that results for all the meat quality traits measured in the present experiment, for both the $\mathrm{H}$ group and the $\mathrm{C}$ group, lay within the normal values suggested for pork (Joo et al., 1995, 1999).

Muscle fiber size also has been negatively related to meat quality, particularly to decreased water-holding capacity and tenderness (Karlsson et al., 1999; Rehfeldt et al., 1999; Gondret et al., 2006). Strong fiber hypertrophy reduces the capacity of fibers to adapt to activity-induced demands, which in turn may be associated with poor meat quality in modern meat-type pigs (Henckel et al., 1997; Rehfeldt et al., 1999). In the present study, pigs born to $\mathrm{H}$ sows showed type IIB fibers with a greater mean cross-sectional area compared with pigs born to $\mathrm{C}$ sows, although neither drip loss nor meat tenderness (TPA test) were apparently affected by sow nutrition during midgestation.

\section{Concluding Remarks}

Overall, feeding pregnant sows amounts above the requirement during the period of $\mathrm{Sc}$ muscle fiber formation affected muscle fiber characteristics (number, size, and proportion of fiber types). Thus, the results support the theory of "fetal programming of postnatal performance" reported by Wu et al. (2004) and Foxcroft et al. (2006), among others, at least in terms of muscle tissue development. However, the results obtained were not consistent with the hypothesis tested. Morphologically, extra feed supplemented during midpregnancy led to fewer but larger (in area) muscle fibers and a smaller percentage of type IIB fibers. These changes did not lead to clear and beneficial effects on postnatal growth performance of the progeny, but caused an effect on some meat quality traits. However, the underlying mechanism for this effect and whether it is consistent in pigs from other, less disadvantaged BW groups remains unknown and requires further investigation.

\section{LITERATURE CITED}

Bee, G. 2004. Effect of early gestation feeding, birth weight, and gender of progeny on muscle fiber characteristics of pigs at slaughter. J. Anim. Sci. 82:826 836.

Boume, M. C. 1978. Texture profile analysis. Food Technol. 72:62 66.

Cerisuclo, A., R. Sala, G. Nürnberg. M. D. Bancells, and C. Rehfeldt. 2007. How many muscle samples are required to obtain reliable estimations of muscle fibre characteristics from pig longissimus muscle? Meat Sci. 76:583-587.

CIE (Commission Internationale de l'Eclairage). 1976. Colorimetry. Publ. Vol. 15. Bureau Central, Vicuna, Austria.

Close, W. H., and D. J. A. Cole. 2003. Nutrition of Sows and Boars. Nottingham University Press, Nottingham, UK.

Deprenx, F. F. S., A. L. Grant, and D. E. Gerrard. 2002. Influences of halothane genotype and body-weight on myosin heavy chain composition in pig muscle as related to meat quality. Livest. Prod. Sci. 73:265-273.

Dwyer, C. M., N. C. Stickland, and .J. M. Fletcher. 1994. The influence of maternal mutrition on muscle fiber number development in the porcine fetus and on subsequent postnatal growth. J. Anim. Sci. 72:911-917.

Foxcroft, G. R., W. T. Dixon, S. Novak, C. T. Putman, S. C. Town, and M. D. A. Vinsky. 2006. The biological basis for prenatal programming of postnatal performance in pigs. J. Anim. Sci. 84(Suppl. E):E105-E112.

Franck, M., P. Figwer, C. Godfraind, M. T. Poirel, A. Khazzaha, and M. M. Ruchoux. 2007. Could the pale, soft, and exudative condition be explained by distinctivo histological characteristics? J. Anim. Sci. 85:746-753.

Gatford, K. L., J. E. Ekcrt, K. Blackmore, M. J. De Blasio, J. M. Boyce, J. A. Owens, R. G. Campbell, and P. C. Owens. 2003. Variable matemal nutrition and growth hormone treatment in the second quarter of pregnancy in pigs alter semitendinosus muscle in adolescent progeny. Br. J. Nutr. 90:283 293.

Gondret, F., L. Lefaucheur, H. Juin, I. Louveau, and B. Lebret. 2006. Low birth weight is associated with enlarged nutscle fiber area and impaired meat tendemess of the longissimus muscle in pigs. J. Anim. Sci. 84:93-103.

Henckel, P., N. Oksbjerg, E. Erlandsen, P. Barton-Gade, and C. Bejerholm. 1997. Histo-and biochemical characteristics of the longissimus dorsi muscle in pigs and their relationships to performance and meat quality. Meat Sci. 47:311 312. 
Heyer, A., H. K. Andersson, J. E. Lindberg, and K. Lundströn. 2004. Effects of extra maternal feed supply in early gestation on sow and piglet performance and production and meat quality of growing/finishing pigs. Acta Agric. Scand. A 54:44 5.5.

Hoshi, E. H., N. A. N. Fonscen, J. W. Pinheiro. A. M. Bridi, and C. A. da Silva. 2005. Muscle fibre number and growth performance of pigs from sows treated with ractopanine. Asian-aust ralas. J. Anim. Sri. 18:1492 1497.

Joo, S. T., R. G. Kanlfman, B. C. Kin, and C. J. Kim. 1995. The relationship between color and water holding capacity in prostigor porcine longissimus muscle. J. Muscle Foods 6:211-226.

Joo, S. T., R. G. Kantman. B. C. Kim, and G. B. Park. 1999. The relationship of sarcoplasmic and myofirbillar protein solubility to colour and water-holding capacity in porcine longissimus muscle. Meat Sci. 52:291-297.

Karlsson, A. H., R. E. Klont, and X. Femande\%. 1999. Skeletal muscle fibres ats factors for pork quality. Livest. Prod. Sci. 60:255-269.

Larzul, C, L. Lefancherur. P. Ecolan, J. Gogne, A. Talmnant, P. S(llier, P. Lo Roy. and G. Monin. 1997. Phenotypic and genetic paraneter's for longissimus muscle fiber characteristios in relation to growth, carcass, and meat quality traits in Large White pigs. J. Aninn. Sci. 75:3126-3137.

Latorre, R., F. Gil. J. M. Vazquez, F. Noreno, F. Mascarello, and G. Ramirez. 1993. Skeletal muscle filore types in the (log. J. Anat. 182:329 337

Lawlor, P. G., P. B. Lymch, M. K. O'Comell, L. McNamara, P. Reid, and N. C. Stickland. 2007. The influence of over fecding sows during gestation on reproductive performance and pig growth to slaughter. Arch. Tiers 50(Special Issinc):82 91

Lefaucheur, L. 2006. Myofibre typing and its relationships to growth performance and meat quality. Arch. Tier\%. 49:-1-17.

Lefancheur, L., P. Ecolan, E. M. Barzic, J. Marion, and J. Le Dividich. 2003. Early postnatal food intake alter's myofiber's maturation in pig skeletal muscele. J. Nutr. 133:140 147.

Lefanchenu, L., P. Ecolan. L. Plantard, and N. Gueguen. 2002. N('w insights into muscle fiber types in the pig. J. Histochem. Cytochem. 50:719 730 .

Miller, H. M.. G. R. Foxcroft, and F. X. Ahene. 2000. Increasing food intake in late gestation improved sow condition throughout lactation but did not affect piglet viability or growth rate. Anin. Sci. 71:141 148.

Musser. R.. D. L. Davis. M. D. Tokadd. J. L. Nolssen, S. S. Dritz, and R. D. Goorlband. 2006. Effects of high feed intake during early gestation on sow performance and offeppring growth and carcass characteristics. Anim. Food Sci. Terhnos. 127:187 199.

Nissen, P. M., V. O. Daniclicen, P. F. Jorgensen. and N. Oksbjerg. 2003. Increased matermal mutrition of sows has no boneficial effects on muscle fiber number or pestnatal growth and lats no impact on the meat culality of the offspring. J. Anim. Sci. $81: 30183027$.

NRC. 1998. Nutrient Requirements of Swine. 10th rev. exl. Natl. Acaul. Press, Washington, DC.

Oksbjerg. N.. J. S. Potersen, 1. L. Sorensen, P. Honckel. AI. Vestergelard, P. Ertbjerg, A. I. Moller, C. Bejerhohnt, ancl S. Stoicr. 2000. Long-term changes in performance and meat quality of Danish Landrace pigs: A study on a corrent compared with an minproved genotype. Anim. Sci. 71:81 92.

Resmussien. A.. and J. R. Andersson. 1996. New method for determination of drip loss in pork muscles. Pages 286287 in Proce. $421 \mathrm{~d}$ Int. Congr. Mcat Sci. Techmol., Lillelhammer. Norway.

Rehfeldt. C.. I. Fiedler, G. Distl. and K. Ender. 2000. Myogenesis and postnatal muscle coll growth as influenced by solection. Livent. Prod. Sci. 66:177 188.

Relifeldt. C.. I. Fiedler, and N. C. Sticklaukl. 2004. Number and sizo of muscle fibres in relation to nuat production. Pages $1-23$ in Muscle Development of Livestock Aninials. M. F. W. te Pass. M. E. Everts. and H. P. Hadagsuman. edl. ('ABI J'ublishing, Oxforlshire, UK.

Rolffeldt. C.. G. Kuhn, J. Vauselow. R. Furbiss. I. Findler. G. Nurnberg. A. K. Clelland, N. C. Stickland, and K. Ender. 2001. Matermal treatmont with somatotropin cluring carly gestation affects basic events of myogenesis in pigs. Coll Tissue Res. $306: 429-440$.

Rohfektt, C., N. C. Stickland. I. Fiedler. and .J. Wegner. 1999. Envirommental and genctic factors as sources of variation in skeletal muscle fibre number. Basic Appl. Myol. 9:235 253.

Speer. V. C. 1990). Partitioning nitrogen and anino acids for pregnancy and lactation in swine: A review. J. Anim. Sci. 68:553 561.

Swatland. H. J.. and R. G. Cassens. 1973. Prematal development. histochenistry, and innervation of porcine nunsele. J. Anim. Sci. $36: 34: 354$.

Wigmore. P. M., and N. C. Stickland. 1983. Mascle development in large and sinall pig fetuses. J. Anat. 137:235 245.

Wu, G.. F. W. Bazer. T. A. Cudd, C. J. Neininger, and T. E. Spencer. 2004. Maternal mutrition and fetal development. J. Nutr. $134: 21692172$. 